\title{
Immunotoxicological Effects of Agent Orange Exposure to the Vietnam War Korean Veterans
}

\author{
Hyoung-Ah KIM'1, Eun-Mi KIM², Yeong-Chul PARK², Ji-Yeon YU³, Seung-Kwon HONG \\ Seong-Hoon JEON ${ }^{4}$, Kui-Lea PARK ${ }^{5}$, Sook-Jin HUR ${ }^{6}$ and Yong HEO ${ }^{2 *}$ \\ ${ }^{1}$ Department of Preventive Medicine, College of Medicine, The Catholic University of Korea, 505 Banpo-dong, \\ Seoul, Korea \\ ${ }^{2}$ Department of Occupational Health, College of Natural Sciences, Catholic University of Daegu, 330 Kumrak 1- \\ ri, Hayang-eup, Kyongsan-si, Kyongbuk, Korea \\ ${ }^{3}$ School of Public Health, Seoul National University, 28 Yeonkun-dong, Seoul, Korea \\ ${ }^{4}$ College of Medicine Asan Medical Center, University of Ulsan, 388-1 Poongnap-dong, Seoul, Korea \\ ${ }^{5}$ National Institute of Toxicological Research, Korea Food \& Drug Administration, 5 Nokbun-dong, Seoul, Korea \\ ${ }^{6}$ Division of Bacterial Products, Korea Food \& Drug Administration, 5 Nokbun-dong, Seoul, Korea
}

Received April 28, 2003 and accepted May 28, 2003

\begin{abstract}
Immunomodulatory effects of 2,3,7,8-tetrachlorodibenzo-p-dioxin (TCDD) demonstrated using animals are thymic atrophy, downregulation of cytotoxic $T$ or $B$ lymphocyte differentiation or activation, whereas human immunotoxicities have not been investigated well. This study was undertaken to evaluate overall immunologic spectrum of the Vietnam War Korean veterans exposed to Agent Orange contaminated with TCDD. Quantity of red blood cells, hemoglobin and hematocrit in the veterans suffered from chronic diseases associated with Agent Orange exposure (Veteranspatient group) were decreased in comparison with those of the veterans without the diseases and the age-matched healthy controls, but no differences in leukocyte populations. Plasma IgG levels were lowered in the veterans than the controls, owing to significant decrease in the IgG1 levels. Increase in the IgE levels was observed in the plasma from the veterans. Alteration of $\mathrm{T}$ cell-mediated immunity was also resulted from activation of peripheral blood mononuclear cells with polyclonal $\mathbf{T}$ cell activators. Production of IFN $\boldsymbol{\gamma}$, a major cytokine mediating host resistance against infection or tumoregenesis, was lowered in the veterans-patient group. However, production of IL-4 and IL-10, representative cytokines involved with hypersensitivity induction, was enhanced in the patient group. Overall, this study suggests that military service in Vietnam and/or Agent Orange exposure disturbs immune-homeostasis resulting in dysregulation of $B$ and $T$ cell activities.
\end{abstract}

Key words: Agent Orange, Vietnam War Veterans, RBC, Imunoglobulins, Cytokines, Autoantibodies

\section{Introduction}

The Vietnam War Korean veterans, who did military services from 1964 to 1973 in Vietnam, could be exposed to Agent Orange contaminated with TCDD through participation on spraying Agent Orange. Amount of Agent Orange sprayed by Korean soldiers is estimated as much as

*To whom correspondence should be addressed.
500 thousand gallons ${ }^{1}$. Among approximately 320 thousand Korean soldiers dispatched to Vietnam, over 90 thousand veterans have reported to have health problems related with Agent Orange exposure. Number of the veterans registered as the patient definitely connected with Agent Orange exposure is currently 17,711 veterans, and 46,249 veterans as the patient probably associated with the exposure ${ }^{2}$. Based on the results of two Governmental epidemiologic studies, peripheral nerve disease is the most prevalent disease 
followed by lung cancer, Buerger's disease, larynx cancer, non-Hodgkin's lymphoma, and chloracne in the veterans registered as the patient connected with Agent Orange exposure ${ }^{1,3)}$. Concerning on the veterans enrolled as the patient probably associated with Agent Orange exposure, hypertension was the most prevalent disease followed by diabetes mellitus, seborrheic dermatitis, central nervous diseases, liver diseases, multifocal neuropathy, cancer, hyperlipidemia, cerebrovascular disease, ischemic heart disease, and other skin diseases such as chronic urticaria, psoriasis vulgaris. Considering pathogeneses involved with the diseases addressed above, immune system is assumed to be a potential target of TCDD contained in the Agent Orange, but no systemic investigation was performed to evaluate magnitude of immunotoxicities in the Korean veterans exposed to Agent Orange.

TCDD has been reported to suppress humoral immunity associated with inhibition of B cell differentiation and activation in experimental animals ${ }^{4-6)}$. Furthermore, immunotoxicities on rodent $\mathrm{T}$ cells have been demonstrated, i.e., suppression of cytotoxic T lymphocyte activity, enhancement of activation-induced $\mathrm{T}$ cell death, or inhibition of helper T cell-derived cytokines ${ }^{7-9)}$. However, human studies did not show a consistent relationship between TCDD exposure and alteration in immune response ${ }^{10,11)}$. This inconsistency may be derived from differences in study details, e.g., characteristics on study subjects, magnitude of TCDD exposure, interval from exposure to study, or criteria for control selection, and so forth. Therefore, we investigated for the first time in Korea whether exposure to Agent Orange modifies immunological spectrum of the Vietnam War veterans. The results obtained show that military service in Vietnam and/or Agent Orange exposure may contribute toward alteration in distribution of plasma IgG subclasses, $\mathrm{T}$ cell subset activity, and qualitative characteristics of red blood cells (RBC).

\section{Materials and Methods}

\section{Subjects}

Study subjects were classified into three groups based on the Agent Orange exposure history and their health status. The veterans-patient group was composed of veterans suffering from chronic illness and exposed to 2,3,7,8tetrachlorodibenzo-p-dioxin (TCDD) during their operation in various areas of Vietnam such as Nha Trang, Cam Ranh, Qui Nhon, Tuy Hoa, Nin Hoa, or Da Nang where Agent Orange contaminated with TCDD had been sprayed during the Vietnam War. They were randomly selected among the
Vietnam veterans who visited a veterans hospital in Seoul for the Agent Orange Registry health examination. The veterans-normal group was composed of veterans, who had military service in the various locations described above during the war, but no chronic illness associated with Agent Orange exposure. Control volunteers, age-matched $( \pm 5$ years) with the veterans-patient subjects, were chosen among healthy subjects visiting a general hospital in Seoul for routine health examination and with no Vietnam War military service. Number of study subjects for each group was twenty-four, twenty-seven, and thirty-six, and their age (mean $\pm \mathrm{SD}$ ) was $55.3 \pm 4.3,55.2 \pm 3.43$, and $48.2 \pm 2.9$ years for the veteranspatient, the veterans-normal, and the control, respectively. Informed consent was obtained from each subject prior to their participation in the study. Health status of the participants were investigated clinically by specialist of rehabilitation medicine or family medicine. All sampling procedures complied with the institutional guidelines governing the use of human subjects in research by the Institute for Occupational and Environmental Health, Korea where the correspondence author was employed at the beginning of this study.

\section{Peripheral blood analysis}

Hematological parameters including number and proportion of white blood cell (WBC), red blood cells (RBC), lymphocyte, monocyte, granulocyte, platelet were determined using Coulter counter (Beckman coulter, Fullerton, CA). Hemoglobin concentrations and hematocrit values were also measured.

For investigation on lymphocyte activities, peripheral blood mononuclear cells (PBMC) were isolated by FicollHypaque density gradient centrifugation (Amersham Pharmacia Biotech, Upsala, Sweden). PBMC $\left(1 \times 10^{6}\right)$ were stimulated with 5 ng phorbol 12-myristate 13-acetate (PMA, Sigma, Saint Louis, MO) plus 500 ng ionomycin (Sigma), or $5 \mu \mathrm{g}$ phytohemagglutinin (PHA, Sigma) alone for 48 or 72 hours. The highest levels of cytokine production were observed at the stated concentrations of stimulants, and culture supernatants collected at $72 \mathrm{~h}$ were considered more reproducible and more representative owing to higher production of IL-4 and IFN $\gamma$ (data not shown). Culture medium was RPMI 1640 supplemented with nonessential amino acids $(1 \mathrm{mM})$, sodium pyruvate $(1 \mathrm{mM})$, sodium bicarbonate (1\%) from Biowhittaker (Walkersville, MD), glutamine ( $2 \mathrm{mM}$ ), $50 \mu \mathrm{M}$ 2-mercaptoethanol from Sigma, $1 \%$ penicillin-streptomycin-fungizone mixture (Gibco-BRL, Grand Island, NY), and heat-inactivated fetal bovine serum (10\%, FBS, Gibco-BRL). 


\section{Determination of cytokine concentration}

Interleukin-4 (IL-4), IL-10, IFN $\gamma$, and Tumor necrosis factor (TNF) $\alpha$ in culture supernatants were assayed by a sandwich ELISA using the method supplied by PharMingen (San Diego, CA) and previously described ${ }^{12)}$. The capture and detection mAbs pairs were as follows: IL-4, 8D4-8/MP425D2; IL-10, JES3-19F1/JES3-12G8; IFN $\gamma$, NIB42/4S.B3; TNF $\alpha$, MAb1/MAb11. The plates (Immulon IV, Dynatech, Chantilly, VA) were read using an ELISA reader (Bio-Tek EL800, Winooski, VT) at $405 \mathrm{~nm}$, which automatically calculated the concentration of cytokines from the standard curves. The lower limit of detection was $15 \mathrm{pg} / \mathrm{ml}$ for IL-4, $30 \mathrm{pg} / \mathrm{ml}$ for IL-10, $100 \mathrm{pg} / \mathrm{ml}$ for IFN $\gamma$, and $60 \mathrm{pg} / \mathrm{ml}$ for TNF $\alpha$.

\section{Quantification of plasma IgG subclass}

The level of IgG subclasses in the plasma was measured by subclass-specific ELISA as previously described with minor modification ${ }^{13,14)}$. Briefly, Immulon II plates (Dynatech) were coated with capture antibody $(0.2 \mu \mathrm{g} / 100$ $\mu \mathrm{l} /$ well) by overnight incubation at $4^{\circ} \mathrm{C}$. Then the plates were blocked with PBS containing $1 \%$ bovine serum albumin (BSA) for $2 \mathrm{~h}$ at room temperature. Plasma was added to duplicate wells $(100 \mu \mathrm{l} /$ well $)$ at 1:10000 for IgG1, 1:50000 for $\mathrm{IgG} 2,1: 5000$ for IgG3, and 1:25000 dilution for IgG4 with $1 \%$ BSA-PBS followed by overnight incubation at $4^{\circ} \mathrm{C}$. The bound IgG subclass was detected by adding biotin-mouse anti-human IgG $(0.1 \mu \mathrm{g} / 100 \mu \mathrm{l} /$ well, PharMingen $)$ for $2 \mathrm{~h}$ at room temperature. The plates were washed and further incubated with avidin-peroxidase $(0.25 \mu \mathrm{g} / 100 \mu \mathrm{l} / \mathrm{well}$, Sigma) for $1 \mathrm{~h}$. Finally, bound enzyme activity was measured using the substrate 2,2'-azino-bis (3-ethylbenzthiazolone6 -sulfonic acid, Sigma). The optical density was read at $405 \mathrm{~nm}$. The sensitivity of the assays was $5 \mathrm{ng} / \mathrm{ml}$ for $\mathrm{IgG} 1$, $15 \mathrm{ng} / \mathrm{ml}$ for IgG2 and IgG3, and $1.5 \mathrm{ng} / \mathrm{ml}$ for IgG4. Quality control for the assays was performed using WHO reference serum (National Institute for Biological Standards and Control, Hertfordshire, UK) and Human IgG subclass profile ELISA kit (Zymed Laboratories, South San Francisco, CA).

\section{Evaluation of plasma IgE and autoantibody levels}

Quantification of IgE was performed using ELISA kit (IBL Immuno-Biological Laboratories, Hamburg, Germany). Levels of plasma anti-double stranded DNA (ds DNA) was determined using ELISA kit supplied by Scimedx corporation (Denville, NJ) and antibody against the extractable nuclear antigens (ENA) with ELISA kit by BL Diagnostika (Mainz, Germany). The plates were read at $450 \mathrm{~nm}$.

\section{Statistical analysis}

Data were initially evaluated for nominal distribution. Statistical significances among groups were tested using Sigmaplot (SPSS Inc., Chicago, IL, USA) by single-factor ANOVA and Dunnett's t-test or Kruskal-Wallis ANOVA and Dunn's test, depending on normality of data. The significances were further confirmed by Student's $t$-test or Mann-Whitney test. Differences were considered significant when $\mathrm{P}$ was less than 0.05. Logarithmic transformation was used for statistical analyses on plasma concentrations of IgG subclass.

\section{Results}

\section{Description on diseases diagnosed to the veterans}

The veterans-patient group is composed of the Vietnam War veterans diagnosed to have chronic diseases associated with Agent Orange exposure. Among them, twelve veterans $(50 \%)$ had cardiovascular diseases such as hypertension, hemiplegia, cerebral infarction, telangiectasis, or total hip replacement due to avascular necrosis, and five veterans $(21 \%)$ were suffered from nervous system disorders such as lumbar radiculopathy, peripheral neuropathy, or cervical myelopathy (data not shown). Dermal pathogeneses including folliculitis, seborrheic dermatitis, or eczema nummulare were also evident to four veterans (17\%). In addition, diseases at endocrine, musculo-skeletal, neurologic, or respiratory system were diagnosed to eight veterans. Spinal cord tumor or lipoma was present in one subject, respectively. The patient subjects had 1.5 chronic diseases per person.

\section{Monitoring of hematological alterations}

Concerning composition and quantity of peripheral blood cells, white blood cells from the veterans-patient group were not much different from those of other groups. Average number of $\mathrm{WBC}$ was $6.81 \pm 0.26 \times 10^{3} / \mu$ l for the veteranspatient group, $6.74 \pm 0.30 \times 10^{3} / \mu$ f for the veterans-normal group, and $6.41 \pm 0.22 \times 10^{3} / \mu \mathrm{l}$ for the control group. Number of lymphocyte $\left(2.32 \pm 0.11 \times 10^{3} / \mu \mathrm{l}\right)$, monocyte $(0.53 \pm$ $\left.0.03 \times 10^{3} / \mu \mathrm{l}\right)$, or granulocyte $\left(3.96 \pm 0.17 \times 10^{3} / \mu \mathrm{l}\right)$ for the veterans-patient group was not significantly different from those of other groups. Furthermore, we could not find any significant difference in proportion of lymphocyte, monocyte, and granulocyte within leukocyte population (data not shown).

We also compared parameters related with RBC. Average number of RBC $\left(4.42 \pm 0.10 \times 10^{6} / \mu \mathrm{l}\right)$ for the veterans-patient group was significantly lower than those of other groups (Table 1). Even though hemoglobin concentrations and hematocrit values for the veterans-patient subjects were 
Table 1. Lowered RBC parameters in the veterans in comparison with those of the control group

\begin{tabular}{lccc}
\hline \multirow{2}{*}{ Group } & \multicolumn{3}{c}{ RBC parameters (mean $\pm \mathrm{SD})$} \\
\cline { 2 - 4 } & $\begin{array}{c}\text { Number of RBC } \\
\left(10^{6} \mathrm{cells} / \mu \mathrm{l}\right)\end{array}$ & $\begin{array}{c}\text { Hemoglobin } \\
(\mathrm{g} / \mathrm{dl})\end{array}$ & $\begin{array}{c}\text { Hematocrit } \\
(\%)\end{array}$ \\
\hline Veterans-patient & $4.42 \pm 0.10^{*}$ & $14.28 \pm 0.35^{*}$ & $41.48 \pm 1.00^{*}$ \\
Veterans-normal & $4.67 \pm 0.08$ & $14.79 \pm 0.29$ & $43.33 \pm 0.76$ \\
Control & $4.68 \pm 0.06$ & $15.32 \pm 0.17$ & $44.39 \pm 0.51$ \\
\hline
\end{tabular}

Statistically significant differences $(*)$ from the veterans-normal and the control group.

Table 2. Alterations in the levels (mean \pm SD) of plasma IgE and IgG1

\begin{tabular}{lccccc}
\hline \multirow{2}{*}{ Group } & & \multicolumn{4}{c}{ IgG subclasses $(\mathrm{mg} / \mathrm{ml})$} \\
\cline { 3 - 6 } & IgE $(\mathrm{ng} / \mathrm{ml})$ & IgG1 & IgG2 & IgG3 & IgG4 \\
\hline Veterans-patient & $1467 \pm 351^{*}$ & $4.11 \pm 0.74^{* *}$ & $4.47 \pm 0.44$ & $0.81 \pm 0.07$ & $0.22 \pm 0.04$ \\
Veterans-normal & $1693 \pm 577^{*}$ & $5.76 \pm 0.92$ & $4.06 \pm 0.32$ & $0.94 \pm 0.09$ & $0.33 \pm 0.06$ \\
Control & $746 \pm 178$ & $8.75 \pm 1.18$ & $5.73 \pm 0.64$ & $0.88 \pm 0.09$ & $0.33 \pm 0.04$ \\
\hline
\end{tabular}

Statistically significant differences (*) from the control group and significantly lowered $\operatorname{IgG1}$ level (**) in the veterans-patient group compared with that of the other two groups.

within the published normal range (12-18 g/dl for hemoglobin and $36-54 \%$ for hematocrit) ${ }^{15)}$, level of these parameters was significantly lower in the veterans-patient group than in the other two groups.

\section{Alteration in humoral immunity following Agent Orange exposure}

To monitor potential adverse effects on the humoral immunity due to Agent Orange exposure, we determined the plasma immunoglobulin (IgG subclasses and IgE) levels of the veterans-patient subjects and compared them with those of the veterans-normal and the control subjects. IgG is a mediator of humoral immunity against bacterial or viral infection, and normal levels usually reflect normal function of B cells. Abnormal levels of serum IgE and IgG subclass have been reported in various diseases including allergic diseases such as asthma or atopic dermatitis ${ }^{16,17)}$. The plasma IgE level was significantly enhanced in the veterans-patient subjects compared with that of the control subjects (Table 2). However the significantly higher plasma IgE level of the veterans-patient group may not be associated with the diseases occurred in the patients, in that no significant difference was found between the veterans-patient and the veterans-normal group.

Total IgG levels were significantly different among the groups (the veterans-patient, $9.9 \pm 1.0$; the veterans-normal, $11.1 \pm 1.1$; the control, $16.0 \pm 1.5 \mathrm{mg} / \mathrm{ml}$ ). Plasma IgG1 level may be responsible for the difference in the total $\operatorname{IgG}$ levels since IgG1 level was significantly lower in the veterans-patient group $(4.1 \pm 0.7 \mathrm{mg} / \mathrm{ml})$ than in the veteransnormal $(5.8 \pm 0.9 \mathrm{mg} / \mathrm{ml})$ and the control $(8.8 \pm 1.2 \mathrm{mg} / \mathrm{ml})$ group (Table 2), whereas no significant alteration was demonstrated with levels of $\operatorname{IgG} 2, \mathrm{IgG} 3$, and $\mathrm{IgG} 4$ among the groups.

Alteration of $T$ cell-mediated immunity in the veterans exposed to Agent Orange

Exposure to environmental toxicants has been reported to disturb the balance between the regulatory and effector $\mathrm{T}$ cells, which can lead to selective activation or suppression of $T$ cell subsets with production of distinct cytokines resulting in various immunopathologic states in human ${ }^{5,18,19)}$. To determine whether Agent Orange exposure could direct alteration in the functional activities of T lymphocytes, levels of cytokines produced in vitro from $\mathrm{T}$ cells obtained from the veterans-patient subjects were evaluated and compared them with those of the veterans-normal and the control subjects. Higher production of IL-4 and TNF $\alpha$ was achieved through stimulation with PMA plus ionomycin than with PHA, whereas production of IL-10 and IFN $\gamma$ was higher with PHA stimulation than PMA plus ionomycin. Hereafter we present only the data on IL- 4 and TNF $\alpha$ production from T lymphocytes activated with PMA plus ionomycin, vice versa the data on IL-10 and IFN $\gamma$ production from PHA- 
Table 3. Downregulatory production of IFN $\gamma$ and moderately enhanced production of IL-4 and IL-10 from PBMC stimulated with polyclonal $T$ cell activators in the veterans-patient subjects

\begin{tabular}{lccccc}
\hline \multirow{2}{*}{ Group } & \multicolumn{5}{c}{ Cytokine concentration $(\mathrm{pg} / \mathrm{ml})$} \\
\cline { 2 - 6 } & IFN $\gamma$ & TNF $\alpha$ & IL-4 & IL-10 & IL-4: IFN $\gamma$ Ratio \\
\hline Veterans-patient & $11164 \pm 4103^{*}$ & $7027 \pm 1940$ & $151 \pm 78^{* *}$ & $2421 \pm 393$ & $4.95 \pm 1.72^{* *}$ \\
Veterans-normal & $21113 \pm 1599$ & $10049 \pm 1123$ & $125 \pm 23^{* *}$ & $2156 \pm 116$ & $7.04 \pm 1.62^{* *}$ \\
Control & $30378 \pm 8475$ & $6145 \pm 2961$ & $57 \pm 20$ & $1898 \pm 68$ & $1.43 \pm 0.68$ \\
\hline
\end{tabular}

PBMC were stimulated with PHA or PMA plus ionomycin for 3 days. The results are expressed as the means \pm SD of cytokines in the culture supernatants. The ratio (mean \pm SD) was calculated by dividing the amount of IL- 4 by the amount of IFN $\gamma$ production in the same subjects followed by multiplication of 1000 . Statistically significant difference (*) from the veterans-normal and the control group, and significant differences (**) from the control.

activated T lymphocytes.

IFN $\gamma$ production was significantly lower in the veteranspatient group than the other groups (Table 3). Even though IFN $\gamma$ level in the veterans-normal group was higher than that in the veterans-patient group, the IFN $\gamma$ production remained lower than the control group. This result implies that exposure to Agent Orange plays a downregulatory role for IFN $\gamma$ production. With regard to TNF $\alpha$ production, no significant difference was observed among the groups. We also investigated the effect of Agent Orange exposure on the production of IL-4 and IL-10, which are known as type2 cytokines produced from type- $2 \mathrm{~T}$ cells (Th2 and Tc2) ${ }^{20)}$. IL-4 production was elevated in the veterans exposed to Agent Orange in comparison with that of the control subjects (Table 3), but no difference between the veterans-patient and the veterans-normal group was found. Like-wise, production of IL-10 was upregulated in the veterans in comparison with that of the control subjects without statistical significances. To examine the relative increase in IL-4 to IFN $\gamma$ production by PBMC T cells from the Agent Orangeexposed individual subjects, the IL-4: IFN $\gamma$ ratio was calculated (Table 3). The mean ratio for the Agent Orangeexposed was significantly higher (veterans-patient, 4.95; veterans-normal, 7.04) than for the control subjects (1.43).

\section{Quantitative determination of autoantibodies}

In order to monitor potential induction of autoimmunity such as Systemic Lupus Erythematosus, or systemic rheumatic diseases in the veterans exposed to Agent Orange ${ }^{21,22)}$, we evaluated plasma levels of antibody against ds DNA or extractable nuclear antigens. According to the manufacturer's guideline, titer of anti-ds DNA over 25 International Unit (IU) or anti-ENA over 1 Index Value (IV) is considered positive, and titer over 60 IU or $1.2 \mathrm{IV}$ is considered definitely positive. Mean value of the anti-ds DNA antibodies was $17.3 \pm 5.7$ and $21.5 \pm 10.1 \mathrm{IU}$ in the veterans-patient and the veterans-normal subjects, respectively, without significant difference (Fig. 1, left). Mean level of anti-ENA antibodies was not much different between the two groups $(0.21 \pm 0.38$ for the veterans-patient, $0.15 \pm 0.11$ IV for the veteransnormal group, Fig. 1, right). One subject strong positive to anti-ENA antibody was belonging to the veterans-patient group and suffering from total hip replacement due to avascular necrosis. However, the high titer (2.0) of antiENA antibody may not be associated with the disease since the other two veterans with the same disease demonstrated titers below $0.25 \mathrm{IV}$. The data indicates that autoimmune diseases involved with anti-ds DNA or anti-ENA antibody are not resulted from Agent Orange exposure.

\section{Discussion}

Toxicities related with TCDD exposure had been introduced to us through investigation on health outcomes following a herbicide factory explosion at Seveso, Italy in $1976^{23}$. According to a recent report on the Seveso accident ${ }^{10)}$, plasma IgG levels were decreased with increasing TCDD concentration in the plasma, which were measured about 20 years after the accident. Our present study also demonstrated that plasma total IgG levels were significantly decreased in the veterans exposed to Agent Orange (Table 2). In addition, we found that the decrease in IgG levels were attributable to decrease in the levels of IgG1 subclass. Since IgG1 plays a major role for humoral immune response through complement fixation, neutralization, or Fc receptormediated phagocytosis, the IgG1 decrease may lead to downregulation of antibody-mediated host resistance, which could enhance an opportunity of infection or tumor progression $^{16}$. This finding is well consistent with a German study reporting a significant decrease in the plasma concentration of IgG1 in workers exposed to TCDD ${ }^{24)}$. Furthermore, the levels of plasma IgE, a representative 

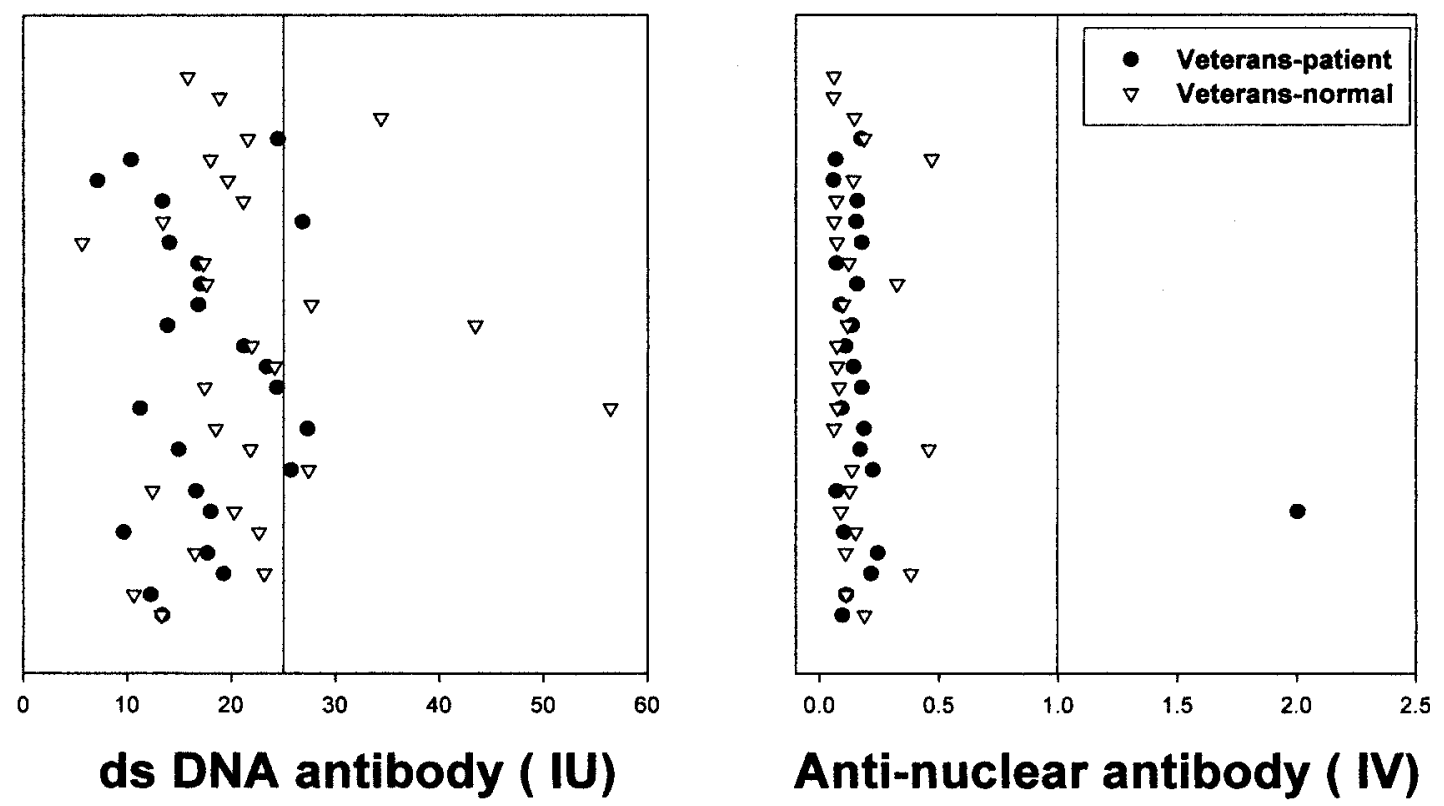

Fig. 1. No strong positive antibody responses to ds DNA and extractable nuclear antigens in the study subjects Vertical line indicates the cut-off value for positive titer of anti-ds DNA (25 IU) or anti-ENA (1 IV).

antibody involved with induction of respiratory or dermal hypersensitive reactions ${ }^{25,26)}$, were also enhanced in the veterans exposed to Agent Orange (Table 2), reflecting an atopic status. Unfortunately there was no previous report regarding effect of TCDD exposure on human plasma $\operatorname{IgE}$ levels, therein we could not conclude the IgE increase as a novel phenomena of TCDD exposure at this moment. However, one in vitro study addressing TCDD-induced enhancement of IgE synthesis from IL-4 plus CD40 mAbstimulated human $\mathrm{B}$ cells $\mathrm{s}^{27}$ is supporting the result of our investigation. The involvement of IgE increase in the TCDDmediated immune pathogenesis should be tested furthermore.

No obvious alteration was shown on composition and quantity of peripheral leukocyte population in the Vietnam War Korean veterans compared with that of the control subjects. Other studies, evaluating a relationship between changes in immunologic parameters and TCDD levels long after the end of exposure, did not find a significant effect of TCDD exposure on quantitative alteration of lymphocyte population including $\mathrm{CD} 4^{+} \mathrm{T}$ cell, $\mathrm{CD} 8^{+} \mathrm{T}$ cell, $\mathrm{B}$ lymphocyte, and natural killer cell ${ }^{11,28,29)}$. Regarding RBC parameters, there were decreases in the number of RBC, hemoglobin concentration, and hematocrit value for the veterans in comparison with those of the control subjects (Table 1). These findings suggest that RBC could be a target of TCDDmediated immunotoxicity. But these decreases are not likely to be of clinical significance since the values are all within the normal range. Even though very few data available for the hematopoietic effects of TCDD exposure in humans, one study described no difference in the RBC parameters listed above between the Vietnam War American veterans and their control ${ }^{30)}$. It will be difficult at the present moment to conclude whether TCDD exert its regulatory effects on RBC. It may be necessary to consider RBC as a potential target of TCDD-mediated toxicity and to further investigate TCDD effect on RBC hematopoiesis or clinical sequelae relevant to the present findings by recruiting much more study subjects in future.

The present study suggests that TCDD exposure may suppress host defense against infectious microorganisms, because IFN $\gamma$, a major cytokine mediating cell-mediated immune responses for the clearance of infectious pathogens, was significantly lowered in the veterans-patient group (Table 3 ). IFN $\gamma$ is mainly produced by natural killer cells and type1 helper and cytotoxic $\mathrm{T}$ cells, and induces macrophage activation leading to enhanced anti-microbial activity with IL-12 ${ }^{31,32}$. Considering our in vitro experimental scheme using polyclonal $\mathrm{T}$ cell activator, activities of type-1 $\mathrm{T}$ cells may not be completely suppressed in the veterans exposed to TCDD, in that production of TNF $\alpha$, another type1cytokine ${ }^{33,34)}$, was not lowered in the veterans in comparison with that of the control group. In contrast to the IFN $\gamma$ downregulation, production of type- 2 cytokine, IL- 4 and IL-10, was rather enhanced in the veterans (Table 3). Overall, 
our results suggest that exposure to Agent Orange disturbs the homeostasis of $\mathrm{T}$ cell subsets resulting in predominance of type- 2 response mediating by Th2 or Tc2 lymphocytes and concomitant suppression of type- $1 \mathrm{~T}$ cell activities such as IFN $\gamma$ synthesis. Combined with the our result on plasma IgE levels, our study indicates that immune system of the veterans-patient group is clearly skewing toward type-2 response. Orchestration of type- 2 cytokines with $\operatorname{IgE}$ antibody could enhance the susceptibility of the veterans to various allergic diseses ${ }^{35)}$. Meanwhile, environmental toxicants such as lead, mercury, or diesel exhaust particles are known to preferentially drive the immune system toward type-2 response ${ }^{5,18,19,36)}$. Exposure to these toxic chemicals may either contribute the upregulation of type- 2 response in the veterans, or confound a substantial effect of TCDD on the balance between type- 1 and type- 2 response. Psychosocial stress could be considered a confounding factor contributing to the immune-modulation demonstrated at the Agent Orange-exposed veterans in our study. Changes in immune responses have been reported from peoples experiencing psychiatric problems through long-term patient care, examination, marital discord, or individual personal characteristics $^{37)}$. An increased IL-10:IFN $\gamma$ ratio from polyclonally stimulated PBMC was reported in the students stressed with examination ${ }^{38)}$, suggesting a potential association of stress hormones with shift toward type-2 response ${ }^{39}$. Decrease in IgG antibody production after viral or bacterial vaccination was demonstrated to long-term caregivers of dementia patients ${ }^{40,41}$. Therein psychological stress rather than Agent Orange exposure may have a relationship with the immune-dysregulation of the veterans, resulting in skewing toward type- 2 reactivity and lowered plasma IgG level. This explanation may be supported by recent results of the Korean Governmental epidemiologic study ${ }^{1)}$ addressing an association of mental depression or anxiety with self-rating level of Agent Orange exposure.

In conclusion, on the basis of our data with limitation on number of study subjects or information on exposure degree of Agent Orange, immune-alteration is apparently occurred in the Vietnam War Korean veterans. Even though we could not announce TCDD in the Agent Orange as a decisive factor for the disturbance of immune-homeostasis demonstrated in our study, military service in Vietnam and/or Agent Orange exposure could contribute the immune-dysregulation inducing the aberrant generation of immunoglobulins or cytokines. Dysregulation between type- 1 and type- $2 \mathrm{~T}$ cells shown in our study needs further extensive investigation to substantiate effect of TCDD exposure on cellular or humoral immunity in human.

\section{Acknowledgements}

This work was supported by Korea Food \& Drug Administration and Catholic University of Daegu.

\section{References}

1) Ministry of Patriots \& Veterans Affairs and Yonsei Medical Center (2001) Epidemiologic study on Agent Orange-induced health hazards, Korea.

2) Ministry of Patriots \& Veterans Affairs (2003) Agent Orange Registry, Korea.

3) Ministry of Health \& Welfare (1996) Epidemiological results on Agent Orange-associated health risk to the Vietnam War Korean Veterans, Korea.

4) Pohjanvitra R, Tuomisto J (1994) Short-term toxicity of 2,3,7,8-tetrachlorodibenzo-p-dioxin in laboratory animals: effects, mechanisms, and animal models. Pharmacol Rev 46, 483-549.

5) Heo Y, Saxon A, Hankinson O (2001) Effect of diesel exhaust particles and their components on the allergenspecific IgE and IgG1 response in mice. Toxicology 159, 143-58.

6) Suh J, Jeon YJ, Kim HM, Kang JS, Kaminski NE, Yang K-H (2002) Aryl hydrocarbon receptor-dependent inhibition of AP-1 activity by $2,3,7,8$ tetrachlorodibenzo- $p$-dioxin in activate B cells. Toxicol Appl Pharmacol 181, 116-23.

7) Kerkvliet NI, Shepherd DM, Baecher-Steppan L (2002) $\mathrm{T}$ lymphocyte are direct, aryl hydrocarbon receptor (AhR)-dependent targets of 2,3,7,8-tetrachlorodibenzop-dioxin (TCDD): AhR expression in both $\mathrm{CD}^{+}$and $\mathrm{CD}^{+} \mathrm{T}$ cells is necessary for full suppression of a cytotoxic T lymphocyte response by TCDD. Toxicol Appl Pharmacol 185, 146-52.

8) Camacho IA, Hassuneh MR, Nagarkatti M, Nagarkatti PS (2001) Enhanced activation- induced cell death as a mechanism of 2,3,7,8-tetrachlorodibenzo- $p$-dioxin (TCDD)-induced immunotoxicity in peripheral T cells. Toxicology 165, 51-63.

9) Shepherd DM, Dearstyne EA, Kerkvliet NI (2000) The effects of TCDD on the activation of ovalbumin (OVA)specific DO11.10 transgenic CD4+ $\mathrm{T}$ cells in adoptively transferred mice. Toxicol Sci 56, 340-50.

10) Baccarelli A, Mocarelli P, Patterson DG, Bonzini M, Pesatori AC, Caporaso N, Landi MT (2002) Immunologic effects of dioxin: new results from Seveso and comparison with other studies. Env Health Perspect 110, 1169-73. 
11) Michalek JE, Ketchum NS, Check IJ (1999) Serum dioxin and immunologic responses in veterans of Operation Ranch Hand. Am J Epidemiol 149, 1038 46.

12) Kim H-A, Heo Y, Oh S-Y, Lee K-J, Lawrence DA(1999) Altered serum cytokine and immunoglobulin levels in the workers exposed to antimony. Human \& Exp Toxicol 18, 607-13.

13) Braun A, Wiebe P, Pfeufer A, Geßner R, Renz H (1999) Differential modulation of human immunoglobulin isotype production by the neuropeptides substances $\mathrm{P}$, NKA, and NKB. J Neuroimmunol 97, 43-50.

14) Silvy A, Lagresle C, Bella C, Defrance $T$ (1996) The differentiation of human memory $B$ cells into specific antibody-secreting cells is CD40 independent. Eur J Immunol 26, 517-24.

15) Wyngaarden JB, Smith LH, Bennett JC (1988) Cecil textbook of medicine. 19th ed., 2370-80, W.B. Saunders Company, Philadelphia.

16) Jefferis R, Kumararatne DS (1990) Selective IgG subclass deficiency: quantification and clinical relevance. Clin Exp Immunol 81, 357-67.

17) Cookson (2002) Genetics and genomics of asthma and allergic diseases. Immunol Rev 190, 195-206.

18) Kimber I, Selgrade MK (1998) T lymphocyte subpopulations in immunotoxicology. 1st ed., 157-294, John Wiley \& Sons, New York.

19) Heo Y, Lee WT, Lawrence DA (1998) Differential effects of lead and cAMP on development and activities of Th1- and Th2-lymphocytes. Toxicol Sci 43, 17285.

20) Berner B, Akça D, Jung T, Muller GA, Reuss-Borst MA (2000) Analysis of Th1 and Th2 cytokines expressing $\mathrm{CD}^{+}$and $\mathrm{CD} 8^{+} \mathrm{T}$ cells in rheumatoid arthritis by flow cytometry. J Rheumatol 27, 1128-35.

21) Tan TM (1989) Antinuclear antibodies: Diagnostic markers for autoimmune diseases and probes for cell biology. Adv Immunol 44, 93-151.

22) Vaile JH, Dyke L, Kherani R, Johnston C, Higgins T, Russell AS (2000) Is high titre ANA specific for connective tissue disease? Clin Exp Rheumatol 18, 433 8.

23) Bertazzi PA, Consonni D, Bachetti S, Rubagoti M, Baccarelli A, Zoccheti C (2001) Health effects of dioxin exposure: a 20-year mortality study. Am J Epidemiol 153, 1031-44.

24) Neubert R, Maskow L, Triebig G, Broding HC, JacobMuller U, Helge H, Neubert D (2000) Chlorinated dibenzo-p-dioxins and dibenzofurans and the human immune system: 3. plasma immunoglobulins and cytokines of workers with quantified moderatelyincreased body burden. Life Sci 66, 2123-42.

25) Nel AE, Diaz-Sanchez D, Ng D, Hiura T, Saxon A(1998) Enhancement of allergic inflammation by the interaction between diesel exhaust particles and the immune system. J. Allergy Clin Immunol 102 (4 pt 1), 539-54.

26) Peden DB (2000) Development of atopy and asthma; candidate environmental influences and important periods of exposure. Environ Health Perspect 108 (Suppl 3), 475-82.

27) Takenaka H, Zhang K, Diaz-Sanchez D, Tsien A, Saxon A (1995) Enhanced human IgE production results from exposure to the aromatic hydrocarbons from diesel exhaust: direct effects on B-cell IgE production. $\mathbf{J}$ Allergy Clin Immunol 95, 103-15.

28) Halperin W, Vogt R, Sweeney MH, Shopp G, Fingerhut M, Petersen M (1998) Immunological markers among workers exposed to 2,3,7,8-tetrachlorodibenzo-p-dioxin. Occup Environ Med 55, 742-9.

29) Ernst M, Flesch-Janys D, Morgenstern I, Manz A (1998) Immune cell functions in industrial workers after exposure to 2,3,7,8-tetrachlorodibenzo- $p$-dioxin: dissociation of antigen-specific T-cell responses in cultures of diluted whole blood and of isolated peripheral blood mononuclear cells. Environ Health Perspect 106 (Suppl 2), 701-5.

30) Michalek JE, Longnecker MP, Burton JE (2001) relation of serum 2,3,7,8-tetrachlorodibenzo-p-dioxin (TCDD) level to hematological examination results in veterans of Operation Ranch Hand. Arch Environ Health 56, 396-405.

31) Losana G, Rigamonti L, Borghi I, Assenzio B, Ariotti S, Jouanguy E, Altare F, Forni G, Casanova J-L, Novelli F (2002) Requirement for both IL-12 and IFN- $\gamma$ production by human T cells. Eur J Immunol 32, 693700 .

32) Aderem A, Underhill DM (1999) Mechanisms of phagocytosis in macrophages. Annu Rev Immunol 17, 593-623.

33) Ho JW, Liang RH, Srivastava G (1999) Preferential type-1 cytokine gene expression in peripheral T-cell lymphomas. Hematol Oncol 17, 117-29.

34) Kostense S, Sun WH, Cottey R, Taylor SF, Harmeling S, Zander D, Small PA, Bender BS (1998) Interleukin12 administration enhances Th1 activity but delays recovery from influenza A virus infection in mice. Antiviral Res 38, 117-30.

35) Ono SJ (2000) Molecular genetics of allergic diseases. 
Annu Rev Immunol 18, 347-66.

36) Krieger J, Heo Y, Lawrence DA (1998) Oxidative stress and heavy metal modification of $\mathrm{T}$ lymphocyte subsets. In: T-Lymphocyte Subpopulations in Immunotoxicology. eds. by Kimber I, Selgrade MK, 103-19, John Wiley \& Sons, New York.

37) Kiecolt-Glaser JK (1999) Stress, personal relationships, and immune function: health implications. Brain Behav Immun 13, 61-72.

38) Marshall GD, Agarwal SK, Lloyd C, Cohen L, Henninger EM, Morris GJ (1998) Cytokine dysregulation associated with exam stress in healthy medical students. Brain Behav Immun 12, 297-307.
39) Elenkov IJ, Chrousos GP (1999) Stress hormones, Th1/ Th2 patterns, pro/anti-inflammatory cytokines and susceptibility to disease. Trends Endocrinol Metabol 10, 359-68.

40) Vedhara KV, Cox NKM, Wilcock GK, Perks P, Hunt M, Anderson S, Lightman SL (1999) Chronic stress in elderly carers of dementia patients and antibody response to influenza vaccination. Lancet $\mathbf{3 5 3}, 627$ 31.

41) Glaser R, Sheridan J, Malarkey WB, MacCallum RG, Kiecolt-Glaser JK (2000) Chronic stress modulates the immune response to a pneumococcal pneumonia vaccine. Psychosom Med 62, 804-7. 